\title{
PENGEMBANGAN METODE ISOLASI KONDROITIN SULFAT DARI TULANG RAWAN SOTONG (Sepia phraonis), PARI (Raja sp.), DAN HIU (Carcharinus falciformes)
}

\section{THE ISOLATION DEVELOPMENT OF CHONDROITIN SULPHATE FROM CUTTLEBONE (Sepia phraonis), RAY'S CARTILAGE (Raja sp.), AND SHARK (Carcharinus falciformes)}

\author{
Dimas Hanindika $^{1}$, Moch. Amin Alamsjah ${ }^{2}$ dan Noor Erma Sugijanto ${ }^{3}$ \\ ${ }^{1}$ Program Pasca Sarjana Universitas Airlangga \\ Kampus B Jl. Airlangga 4-6 - Surabaya, 60286 Telp. 031-5041566 \\ ${ }^{2}$ Fakultas Perikanan dan Kelautan Universitas Airlangga \\ Kampus C Mulyorejo - Surabaya, 60115 Telp. 031-5911451 \\ ${ }^{3}$ Fakultas Farmasi Universitas Airlangga \\ Kampus B Jl. Dharmawangsa Dalam - Surabaya, 60286 Telp. 031-5033710
}

\begin{abstract}
Chondroitin sulfate are drugs for osteoarthritis which usually made from pig cartilage and shark, the material can not be accepted because of the prohibition of pork and rare of shark. This study developed a method of Nakano (2000), Garnjanagoonchorn (2006 ), and Volpi (2009) . Extraction and isolation of chondroitin sulfate from alternative raw materials such as the rays and cuttlefish cartilage materials because both are abundant and cheap. Isolation results were analyzed using Fourier Transform Infrared and Thermal Analysis diffrential, obtained 2.37\% chondroitin sulfate from shark cartilage, 1.57 $\%$ from ray's, while the squid was not obtained chondroitin sulfate.
\end{abstract}

Keywords : chondroitin sulphate, Extraction, Cartilage

Pendahuluan

Kondroitin sulfat adalah senyawa glikosaminoglikan yang tersulfatisasi, rantai kondroitin dapat berupa 100 molekul gula. Kondroitin sulfat merupakan komponen struktural penting dalam tulang rawan dan memberikan pertahanan terhadap kompresi (Baeurle et al., 2009). Kondroitin sulfat bersama glukosamin keduanya adalah komponen penyusun persendian yang telah hampir 40 tahun digunakan sebagai obat atas penyakit osteoartritis (Vangsness et al.,2009).

Kondroitin sulfat dibuat dari tulang rawan (trakea) sapi atau babi, dalam akhir dekade belakangan ini hanya berasal dari trakea babi karena penyakit sapi gila yang melanda Eropa (Mierendorff, 2006), sedangkan dari biota perairan, ikan hiu paling umum digunakan (Garnjanagoonchorn, 2006). Kondroitin berbahan baku tulang rawan babi tidak dapat diterima oleh mayoritas warga Indonesia yang beragama Islam, sedangkan ikan hiu telah ditetapkan sebagai hewan yang terancam punah karena populasinya yang terus menurun dikarenakan perburuan sirip hiu hingga perlu untuk dilindungi (Lucifora et al., 2011). Mengingat hal tersebut diatas diperlukan sumber bahan baku alternatif untuk pembuatan kondroitin sulfat selain babi yang haram dan sirip ikan hiu yang langka dan harganya dipasaran sangat mahal karena termasuk bahan makanan mewah salah satunya sup sirip hiu. Isolasi kondroitin sulfat dapat menggunakan metode asam yaitu ekstraksi menggunakan larutan asam terhadap bahan baku selama kurun waktu dan suhu tertentu seperti pada metode Nakano (2000), atau sebaliknya dengan metode basa seperti pada metode Garnjanagoonchorn (2006). Metode Nakano (2000) memiliki kekurangan berupa peralatan yang sulit didapat untuk tahap isolasi, sedangkan metode Garnjanagoonchorn (2006) membutuhkan bahan pereaksi yang harganya mahal, sehingga diperlukan pengembangan metode ekstraksi dan isolasi yang lebih mudah dan murah.

Penelitian bertujuan untuk mengembangkan metode ekstraksi dan isolasi kondroitin sulfat yang lebih mudah dan murah, dan dapat diterapkan pada bahan baku dari limbah perikanan yang harganya sangat murah dengan kelimpahan yang besar.

\section{Materi dan Metode}

Bahan yang digunakan adalah tulang sotong, tulang rawan ikan pari, tulang sirip ikan hiu, aquades, $\mathrm{NaOH}$ (Sigma Aldrich), asam asetat (Sigma Aldrich), cetylpyridinium cholride (Merck), Enzim Papain, Ethanol 99\%, Methanol, $\mathrm{NaCl}$. 
Penelitian ini bersifat eksploratif laboratorik. Sampel yang berasal dari tulang sotong, tulang ikan pari, dan tulang sirip ikan hiu diperoleh dari pasar ikan Pabean Surabaya. Sampel dari berbagai sumber tersebut diisolasi dengan kombinasi metode Nakano (2000) dan Garnjanagoonchorn (2006).

Tulang rawan dipersiapkan dengan cara dibersihkan dari jaringan lain dan kotoran menggunakan air mengalir, selanjutnya bahan diredam dalam larutan enzim papain selama 24 jam, dan dibersihkan dari sisa-sisa jaringan otot atau lainnya kemudian dijemur dibawah sinar matahari selama 6 jam.

Bahan dipotong kecil-kecil kemudian dihaluskan. Bahan halus seberat 2,1348 gram dari ikan hiu dan 2,0215 gram dari ikan pari dimasukkan kedalam erlenmeyer kemudian ditambahkan air aquades dengan $\mathrm{pH}$ 4,5 sebanyak $20 \mathrm{ml}$, asam asetat digunakan untuk mengasamkan larutan dan mempertahankan keasaman pada $\mathrm{pH}$ tersebut. Erlenmeyer yang sudah berisi bahan tersebut mulutnya ditutup dengan alumunium foil dan dimasukkan ke dalam oven untuk dipanaskan pada suhu $37^{\circ} \mathrm{C}$ selama 7 jam. Evaluasi terhadap larutan dilakukan untuk memastikan $\mathrm{pH}$ dan suhu tetap konstan, jika ada perubahan maka akan dilakukan penyesuaian. Larutan yang didapatkan kemudian didiamkan hingga suhunya sesuai dengan suhu ruang, selanjutnya disaring menggunakan kertas saring untuk memisahkan ampas sisa ekstraksi.

Larutan yang didapatkan kemudian didinginkan selanjutnya disentrifugasi untuk mendapatkan supernatan (acidic water solube fraction), $10 \mathrm{ml}$ supernatan yang didapatkan ditambah Cetylpiridinium Chloride (CPC) 3\% w/v dalam $0,8 \mathrm{M} \mathrm{NaCl}$ kemudian dimasukkan frezer selama 10 menit, larutan disentrifugasi pada $5.000 \mathrm{rpm}$ selama 30 menit, selanjutnya ditambahkan $2 \mathrm{M} \mathrm{NaCl}$ dan disentrifugasi pada $5.000 \mathrm{rpm}$ selama 30 menit selanjutnya diambil supernatannya. Supernatan yang didapatkan kemudian ditambahkan methanol 1:1, selanjutnya disentrifugasi pada $5.000 \mathrm{rpm}$ selama 15 menit pada suhu $4^{\circ} \mathrm{C}$ (sebelumnya dimasukkan frezer selama 10 menit). Supernatan dibuang perlahan menggunakan pipet sehingga hanya tersisa endapan, kemudian tabung diisi dengan etanol $95 \% 10 \mathrm{ml}$ dan disentrifugasi pada $3.000 \mathrm{rpm}$ selama 15 menit. Endapan yang terjadi diambil menggunakan pipet dan dikeringkan pada suhu ruangan

\section{Hasil dan Pembahasan}

Pada akhir tahap ekstraksi didapatkan hasil rendemen berupa serbuk berwarna putih sebanyak 50,8 mg dari hiu yang kemudian diujikan pada FTIR dengan hasil sebagai berikut:

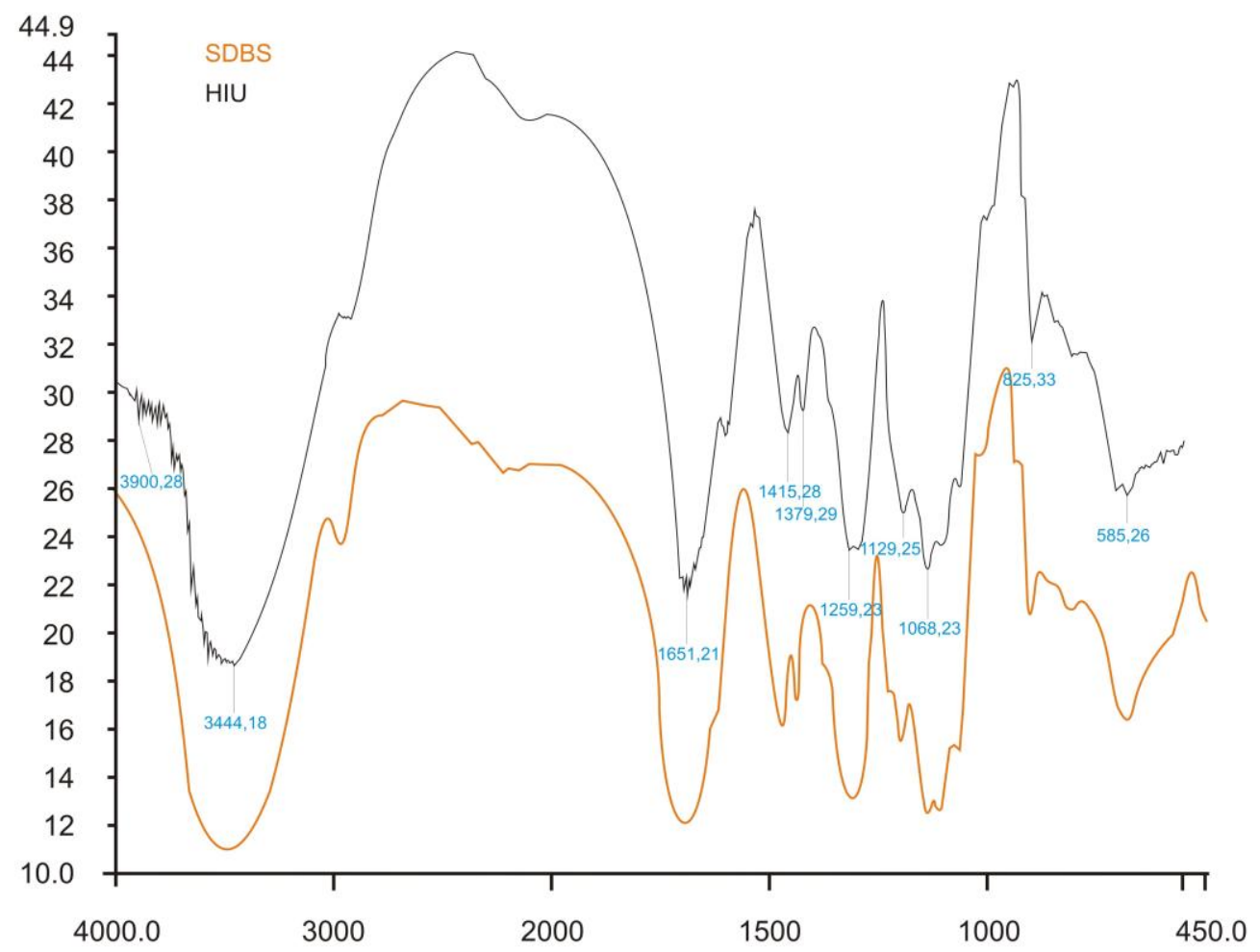

Gambar 1. Overlay spektra sampel hasil isolasi kondroitin sulfat dari tulang rawan hiu (hitam) dengan spektra kondroitin sulfat dari SDBS (oranye) 
Spektra dari sampel ikan hiu menunjukkan serapan pada bilangan gelombang $3.444 \mathrm{~cm}^{-1}$ yang merupakan daerah serapan gugus fungsi $\mathrm{O}-\mathrm{H}$, pita serapan juga terdeteksi pada bilangan gelombang $1.651 \mathrm{~cm}^{-1}$ yang merupakan daerah serapan $\mathrm{C}=\mathrm{O}$.

Pita serapan pada sampel hiu terdapat pada bilangan gelombang $825 \mathrm{~cm}^{-1}$ yang merupakan sidik jari dari kondroitin-6-sulfat, hal ini sesuai dengan hasil penelitian Garnjanagoonchorn et al. (2007). Metode overlay digunakan pada grafik hasil FT-IR untuk mempermudah analisa dalam membandingkan antara sampel dari ikan hiu dan data spektra dari SDBS.

Pada akhir tahap isolasi pada sampel yang berasal dari tulang rawan ikan pari didapatkan hasil rendemen berupa serbuk berwarna putih sebanyak 31,9 mg yang kemudian diujikan pada FT-IR.

Spektra dari sampel ikan pari menunjukkan serapan pada bilangan gelombang $3.434 \mathrm{~cm}^{-1}$ yang merupakan daerah serapan gugus fungsi O-H. Pita serapan juga terdeteksi pada bilangan gelombang $1.655 \mathrm{~cm}^{-1}$ yang merupakan daerah serapan $\mathrm{C}=\mathrm{O}$.

Pita serapan yang kuat pada sampel pari juga terdapat pada bilangan gelombang $825 \mathrm{~cm}^{-}$ 1 yang merupakan sidik jari dari kondroitin-6sulfat. Metode overlay digunakan pada grafik hasil FT-IR untuk mempermudah analisa dalam membandingkan antara sampel dari ikan pari dan data spektra dari SDBS.

Isolasi pada sampel yang berasal dari sotong didapatkan rendemen sebanyak 28,1 mg yang kemudian diujikan pada FT-IR. Spektra dari sampel sotong menunjukkan serapan pada bilangan gelombang $3.459 \mathrm{~cm}^{-1}$ yang merupakan daerah serapan gugus fungsi O-H. Pita serapan lain juga terdeteksi pada bilangan gelombang $1.635 \mathrm{~cm}^{-1}$ yang merupakan daerah serapan $\mathrm{C}=\mathrm{C}$.

Pita serapan yang kuat pada sampel pari juga terdapat pada bilangan gelombang $872 \mathrm{~cm}^{-}$ ${ }_{1}$ dan $712 \mathrm{~cm}^{-1}$ yang merupakan sidik jari dari kalsium karbonat. Dapat diihat gambar overlay antara spektra sampel hasil isolasi yang diduga kondroitin sulfat dari tulang rawan sotong dengan spektra kondroitin sulfat dari SDBS menunjukkan spektra yang tidak identik sehingga hasil isolasi dari tulang rawan sotong bukan merupakan kondroitin sulfat.

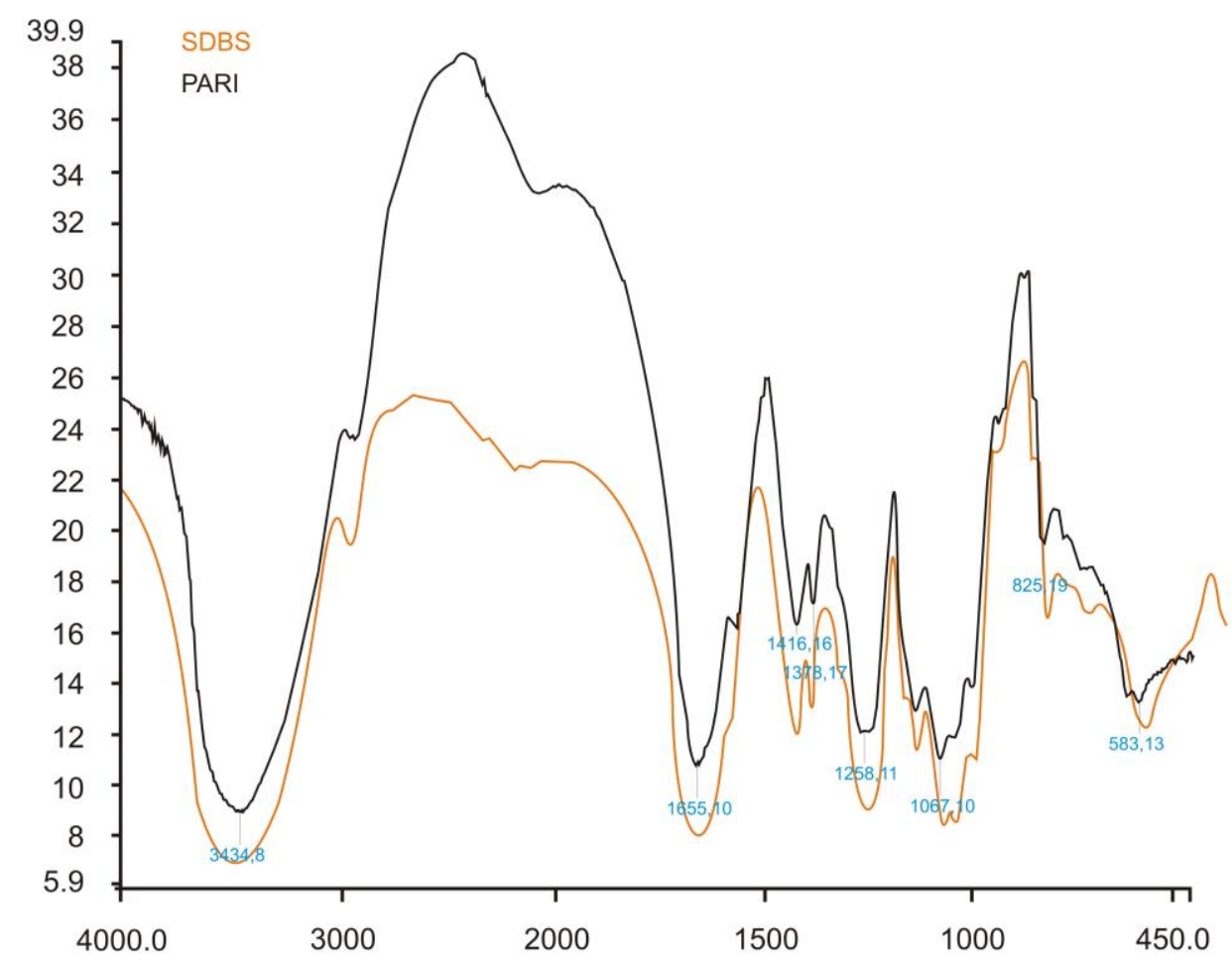

Gambar 2. Overlay spektra sampel hasil isolasi kondroitin sulfat dari tulang rawan pari (hitam) dengan spektra kondroitin sulfat dari SDBS (oranye) 


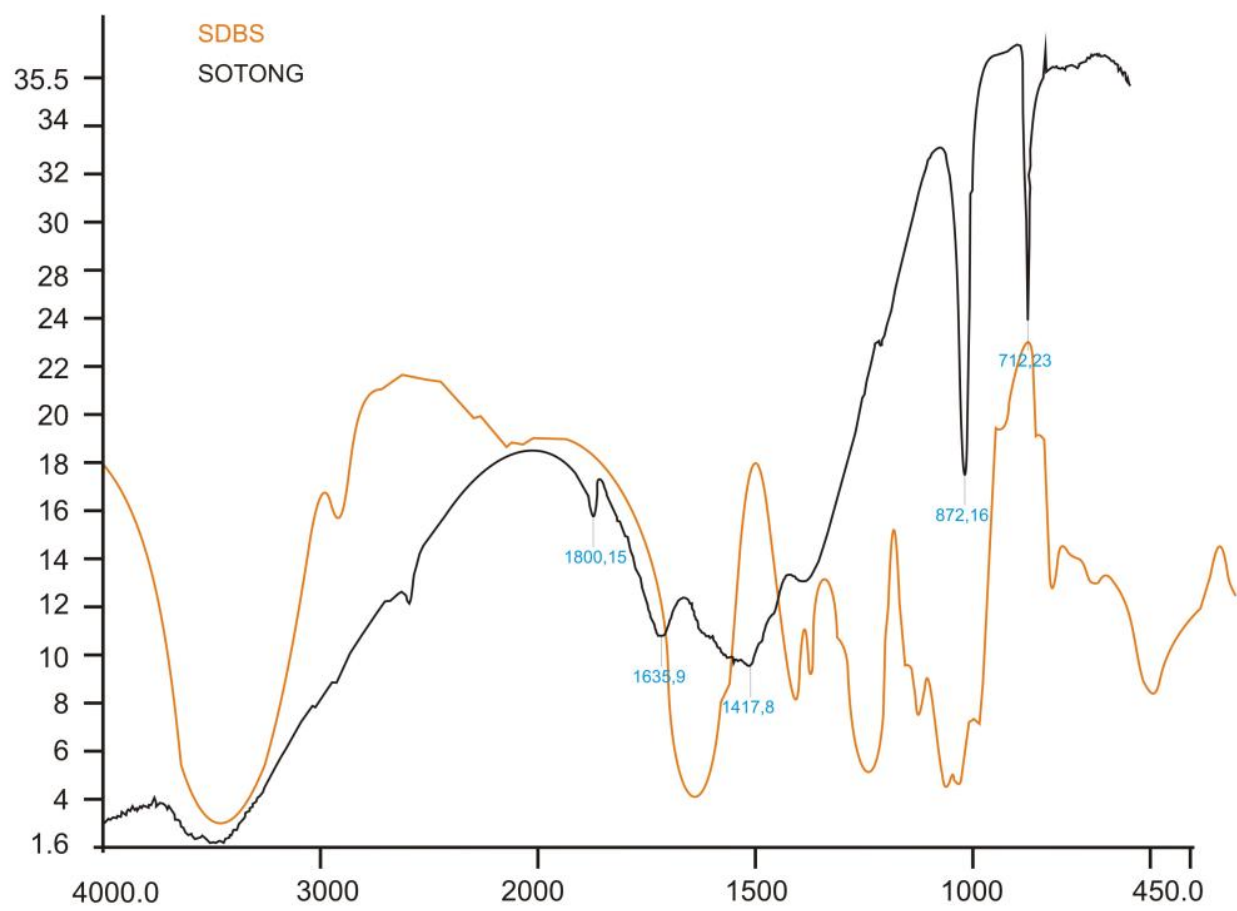

Gambar 3. Overlay spektra sampel hasil isolasi yang diduga kondroitin sulfat dari tulang rawan sotong (hitam) dengan spektra kondroitin sulfat dari SDBS (oranye)

\section{Kesimpulan}

Dari penelitian ini dapat disimpulkan bahwa dengan metode ekstraksi yang telah dilakukan tulang rawan sotong tidak menampakkan adanya kandungan kondroitin sulfat, sedangkan pada tulang rawan ikan pari didapatkan $31,9 \mathrm{mg}$ kondroitin sulfat. Isolasi menggunakan kombinasi antara metode yang dikembangkan dari Nakano (2000) dan metode Garnjanagoonchorn (2006) merupakan metode yang lebih murah dan mudah.

\section{Daftar Pustaka}

Budavari, S. 1996. The Merck Index, ed $12^{\text {th }}$. Whitehouse Station, Merck \& Co. p 371

Creswell, C.J., Runquist, O.A., and Campbell, M. M. 2005. Analisis Spektrum Senyawa Organik. Edisi 3. Diterjemahkan oleh: Padmawinata K, dan Soediro I. Bandung: Penerbit ITB.

Cavalcanti, O.A., Silva, C.C., Pineda, E.A.G., and Hechenleitner, A.A.W. 2005. Synthesis and characterization of phosphate crosslinked chondroitin sulfate: potential ingredient for specific drug delivery. Journal of Acta Farmaceutica Bonaerense 24(2): 234238.

Garnjanagoonchorn W, Wongekalak L, and Engkagul A. 2006. Determination of chondroitin sulfate from different sources of cartilage. Chemical Engineering and Processing Journal 46: 465-471.

Lucifora, L.O., V. B. Gracia, B. Worm. 2011. Global Diversity Hotspots and Conservation Priorities for Shark. Journal of PLoS One, 6 (5) : 1-5.

Mierendorff, H. J. 2006. Analysis of Chondroitinsulphate. http://www. ulexlab.de. 22/01/2013. 6 hal.

Nakano, T., N. Ikawa, and L. Ozimek. 2000. An Economical Method to Extract Chondroitin Sulphate-peptide From Bovine Nasal Cartilage. Journal of Agriculture, 42 : 205-208.

[SDBS] Spectral Database for Organic Compounds. 2006. Advanced industrial and science technology.

Volpi, N. 2009. Quality of Different Chondroitin Sulfate Preparations in Relation to Their Therapeutic Activity. Journal of Pharmacy and Pharmacology, 61 : 1271-1280.

Vangsness, C. T., Spiker, W., Erickson, J. 2009. A Review of Evidence-Based Medicine for Glucosamine and Chondroitin Sulfate Use in Knee Osteoarthritis. Journal of Arthroscopic and Related Surgery. 25(1) : 86-94. 